Article

\title{
Between or Beyond? Jewish British Short Stories in English since the 1970s
}

\section{Axel Stähler}

Department of Comparative Literature, University of Kent, Canterbury CT2 7NF, UK; A.Staehler@kent.ac.uk

Received: 30 July 2020; Accepted: 9 September 2020; Published: 11 September 2020

\begin{abstract}
Looking at short stories by writers as diverse as Brian Glanville, Ruth Fainlight, Clive Sinclair, Jonathan Wilson, James Lasdun, Gabriel Josipovici, Tamar Yellin, Michelene Wandor, and Naomi Alderman, and extending from the center of Jewish British writing to its margins, this article seeks to locate the defining feature of their 'Jewish substratum' in conditions particular to the Jewish post-war experience, and to trace its impact across their thematic plurality which, for the most part, transcends any specifically British concerns that may also emerge, opening up an Anglophone sphere of Jewish writing. More specifically, it is argued that the unease pervading so many Jewish British short stories since the 1970s is a product of, and response to, what may very broadly be described as the Jewish experience and the precarious circumstances of Jewish existence even after the Second World War and its cataclysmic impact. It is suggested that it is prompted in particular by the persistence of the Holocaust and the anxieties the historical event continues to produce; by the confrontation with competing patterns of identification, with antisemitism, and with Israel; and by anxieties of non-belonging, of fragmentation, of dislocation, and of dissolution. Turned into literary tropes, these experiences provide the basis of a Jewish substratum whose articulation is facilitated by the expansion of Jewish British writers into the space of Anglophone Jewish writing. As a result, the Jewish British short story emerges as a multifaceted and hybrid project in continuous progress.
\end{abstract}

Keywords: Jewish British writing; Jewish British short stories; Anglophone Jewish writing; Holocaust writing; antisemitism; patterns of identification; fragmentation; dislocation; dissolution; Israel in literature

Many post-war stories by Jewish British writers are pervaded by a profound sense of unease. They are not "tales of unease," in David Stuart Davies's formulation (Conan Doyle 2008), nor tales of "the new uncanny" in Sarah Eyre and Ra Page's (Eyre and Page 2008); they are not stories of supernatural suspense, but of a deeply felt, existential unease. They are informed by a potentially subliminal sense of discomfort, of anxiety and apprehension, of disquiet; by a sense of disturbance of a state of wholesome equilibrium that, in medical terms, might be described as homeostasis.

Elaborating with recourse to the observation of psychic phenomena a "symptomology" of literary texts, Emily Miller Budick suggests in her enquiry into Cynthia Ozick's short story "Envy; or, The New Yiddish in America" (1969) and the tradition within which it is situated that this literary symptomology frequently gives expression to "inherited" and "communal" traumas (Budick 2007, p. 81). She argues that the manifestations of the literary tradition informed by these texts form something akin to a collective unconscious that, like the mind of an individual, comprises both conscious and unconscious elements (ibid.). Applying her symptomology to Jewish and Jewish American literature, Budick asks:

[W] hat does this body of texts intend to say about the Jewish experience, but also, and just as vitally, what would it particularly like not to say? and what, in this not saying, is it nonetheless saying, which may also be a part of a collective, phantom-like expression of 
secrets that precisely do not belong to the actual lived experience of the particular writer but to the tradition from which he comes? (Ibid.)

The unease I perceive to inform a significant segment of Jewish British short stories seems to me to invite similar questions; it seems, in fact, to be similar in kind to that described by Budick for the Jewish American context.

While I do not wish to claim that this unease informs Jewish British writing in general, nor exclusively the stories of Jewish British writers, I argue that it is characteristic of a particular strain in post-war Jewish British writing which extends far beyond any imaginary center to the margins of what might be designated as 'British-Jewish literature' and reveals the porousness and instability of the term.

This unease seems to be prompted in particular by the persistence of the Holocaust and by the anxieties the historical event continues to produce-even long after the Second World War and its immediate cataclysmic impact; by the confrontation with competing patterns of identification, with antisemitism, and with Israel; and by anxieties of non-belonging, of fragmentation, of dislocation, and of dissolution. Turned into literary tropes, these anxieties inform as "inherited" and "communal" traumas the 'Jewish substratum' of the short stories of the authors discussed here as paradigmatic of this strain, including writers as diverse as Brian Glanville, Ruth Fainlight, Clive Sinclair, Jonathan Wilson, James Lasdun, Gabriel Josipovici, Tamar Yellin, Michelene Wandor, and Naomi Alderman.

These authors, and others, I suggest, advance Jewish British writing into an Anglophone Jewish sphere which offers a connective between 'local' literatures and assists the articulation, however vague, of a Jewish 'substance' or 'substratum,' with which I mean, in a conflation of the latter term's use in geology and biology, a basis layer on which rest subsequent 'sedimentary' layers and which provides nourishment. It seems to me that it is the unease which, to my mind without exception, if to different degrees, informs the stories discussed here that is the defining feature of their Jewish substratum. It originates in conditions particular to the Jewish experience; it pervades these texts across their thematic plurality and transcends, for the most part, any specifically British concerns that may also emerge.

The tension between understanding Jewish short stories in individual national contexts or as part of much wider, transnational and transcultural Jewish creativity, such as the Anglophone sphere (Stähler 2007), illustrates the perennial problem of how to position and contextualize the work of Jewish writers. In an inversion of the usually hyphenated designation 'British-Jewish,' I therefore propose that these writers contribute to what I prefer to call (unhyphenated) Jewish British writing in English, in order to emphasize their Anglophone Jewish affiliation rather than their Britishness.

\section{In English, but beyond British}

In the blurb of an anthology of Modern Jewish Stories, published by Faber and Faber in London in 1963 and edited by the Jewish British writer Gerda Charles (born Edna Lipson; 1914-1996), an image of Jewishness was sketched that was fully compatible with constructions of Englishness (Charles 1963, inside dustjacket flap; Stähler 2016, pp. 328-29). Most conspicuously, this meant that any direct mention of Jewish victimization or of the Holocaust-irreconcilable with British narratives of defiance and victory - was avoided, though the issue was addressed with diffidence by the editor in her introduction (Charles 1963, p. 12). Instead, obviously responding to market expectations, the blurb emphasized Jewish whiteness or even Englishness and demarcated Jewish writing in Britain and the Commonwealth from the multicultural proliferation of "coloured" writing. It suggested a conception not so much of English but of Anglophone Jewish writing which was reflected also in the choice of writers included by the editor, who maintained that "outside Israel," the "great, splendid achievement" of Jewish writing was with "the English-speaking countries: England, the Commonwealth and, above all, America" (ibid.).

Three and a half decades later, Bryan Cheyette sought to counter such a transnational approach in his anthology of Contemporary Jewish Writing in Britain and Ireland and "to focus on one specific narrative 
by tracing a history of extraterritorial or diasporic British-Jewish literature from the early twentieth century to the present day" (Cheyette 1998, p. xiii). Significantly, the editor's emphasis throughout was "as much on the Englishness of Jewish writing as on a supposedly authentic Jewishness," because one cannot, as he suggests, understand the writers in his anthology "without taking note of the national context in which they produce their works" (ibid.). For Jewish writers in Britain, this meant that "most have had to write against the dominance of an oppressive Englishness" (ibid.), as also indicated by the homogenizing blurb to Charles' anthology. Many Jewish British writers have therefore opted for some form of displacing their narratives from England, for removing themselves from the country, or for choosing a kind of 'internal' emigration.

The poet Abraham Stencl (1897-1983), for instance, and the writer Esther Kreitman (1891-1954), elder sister of the much more famous brothers Israel Joshua and Isaac Bashevis Singer, continued to write in Yiddish. Kreitman, who lived in London from 1914 to her death, published a collection of short stories in Yiddish, called Yikhes (1950), which has been translated as Blitz and Other Stories (Kreitman 2004). Should these be considered Jewish British short stories? Or does their original language disqualify them, even if their subject matter is simultaneously inherently Jewish and intensely British? Yiddish as a language of cultural production has faded into insignificance in Britain and it is doubtful whether the translation of Kreitman's stories more than five decades after their initial publication can fully transport them into the present and revoke her self-imposed linguistic extraterritoriality. Yet, it nevertheless documents an attempt to assimilate her stories into a British context, which has evolved significantly since their first publication.

Persuasive as Cheyette's argument is, it is — by necessity — not only dated, but is, moreover, only half of the equation. Social and cultural change in Britain have in the meantime shattered the clay feet of essentialist notions of Englishness; though the most recent developments in the wake of the Brexit referendum (2016), arguably a response to these changes, may well indicate the resurgence of notions of a nostalgic and exclusive Englishness. Nevertheless, as Ruth Gilbert notes, an important shift in British Jewish writing occurred around the turn of the millennium which manifests itself in British Jewish writers "confronting the interface between Jewishness and 'Englishness'" and in their "shaking off a culture of reticence and self-censorship which arguably inhibited previous generations of Anglo-Jewry" (Gilbert 2013, p. 9). In addition, extraterritoriality in relation to the British Isles does not, and cannot, exist in a vacuum. It inadvertently opens up other contact zones, real or imaginary, which offer alternative perspectives on patterns of identification, modes of writing, and thematic choices. To Jewish British writers, bound and bounded by their linguistic origins, no less than for émigré writers adopting English as the vehicle of their cultural creativity, it has in particular been the Anglophone sphere invoked already by Charles that has offered a space of refuge and of development.

In the present day, English is one of the most important languages of Jewish literary production, if not the most important. Its ascendancy is an ongoing process which reflects demographic and cultural change in particular since the post-war period. Another result of this development, also noted by Charles, has been the increasing pre-eminence of the American variety of English- "that most Jewish of languages," as Sander L. Gilman claims (Gilman 1998, p. x). Indeed, echoing Cynthia Ozick, Ilan Stavans suggests that "Jewish letters are no longer local, and English is the new Yiddish, a universal Jewish language for the world to savor," although—arguably another articulation of Jewish unease-he cautions that "judging from the lessons of history, this equation is likely to change time and again" (Stavans 1998, p. 23).

Whether American or British English, either linguistic choice for Jewish cultural production indicates an ambiguity; both not only share significant similarities but are also shared languages (Stähler 2017, p. 732). Moreover, neither is an intrinsically Jewish language, such as Hebrew or Yiddish-notwithstanding such claims as those proffered by Gilman and Stavans and, long before them, Cynthia Ozick with her notorious proposal to re-create English as a new Yiddish (Ozick 1970).

In studies of Jewish writing, it has almost become a trope to invoke the ultimate impossibility of agreeing on a satisfactory definition of either Jewishness or Jewish literature, which is not to say that 
attempts have not been made in abundance (Wirth-Nesher 1994). Nor is it any easier to define Jewish British writing (Sicher 1985; Cheyette 1998; Gilbert 2013). Post-war Jewish cultural production in Britain is to a significant degree determined by émigré writers, which to some extent reflects patterns commensurate with the emerging multicultural society in Britain but which, more specifically, is in many cases related to Jewish displacement as a result of the Holocaust. Yet, even before the Second World War, the impact of exile and migration manifested itself in Jewish writing in Britain. The issue is further confused by the more recent movement of individual writers, which blurs arbitrarily imposed national, if not linguistic, boundaries-the South African writer Dan Jacobson (1929-2014), for instance, settled in London in 1957; the poet and short story writer Ruth Fainlight migrated from America to Britain, as did the novelist, screenwriter, and short story writer Frederic Raphael (both b. 1931); other Jewish writers, such as James Lasdun (b. 1958) and Jonathan Wilson (b. 1950), were born in Britain but now live in America, the latter after having spent some time also in Israel and having adopted American citizenship.

Models of human interaction and literary production are inherently restrictive and problematic. Yet, all of the writers discussed in this article-roughly spanning the period of the 1970s to the present day and most of them still active as writers-venture into an extraterritorial space of Anglophone Jewish writing even as they occupy different degrees of propinquity to either Britishness or Jewishness or both. Anglophone Jewish writing has contributed since the mid-nineteenth century to the cultural cohesion of Jewish communities across the English-speaking diaspora (Stähler 2017, p. 736). More recently, I argue, it has consolidated itself as a particular form of extraterritoriality which, as I seek to show in this article, offers to Jewish British writers not only linguistic validity, comfort, and impact beyond the national sphere, but a safe space for the explicit and implicit engagement with a shared Jewish substratum and, on its basis, also a modicum of literary and cultural cohesion.

\section{Deepening Shadows and Mounting Unease}

After the Second World War, a number of Jewish émigré writers settled in Britain. The literary response to the Holocaust nevertheless emerged only hesitantly in Jewish British writing and has never achieved the prominence it has in contemporary Jewish American literature. It was only since the mid-1950s that writers such as Alexander Baron (1917-1999) and Brian Glanville (b. 1931), neither of whom was an émigré, began to engage with the cataclysmic event from a distance. Both were proponents of what was labeled the "New Wave" of Jewish writing in Britain (Fyvel 1963). In stories such as Baron's "The Anniversary" (1954) and Glanville's "The Survivor" (1961), the ineffable nature of the conflagration is explored through its effect on the lives of survivors and bystanders. In both stories the safe insulation "within the present," in Baron's words, "a blessed, a necessary protection," is compromised (Baron 1954, p. 8). They expose the latent menace and uneasy recognition of the catastrophic mental damage inflicted by the Holocaust as it ruptures the protective shell of a reassembled life in the wake of the traumatic experience (Stähler 2016, pp. 332-33).

While Baron's story is set in France, on 'extraterritorial' soil, "The Survivor," first published in Glanville's 1961 collection A Bad Streak and Other Stories (Glanville 1961, pp. 107-18), is set in England. Once again, it is instructive to consider the volume's blurb, which enthused:

But perhaps outstanding in the collection are Mr. Glanville's studies of the little known world of the professional footballer. Readers of stories like "Everything laid on" and "If he's good enough he's big enough" will be left in no doubt that if he chose he could become the English Ring Lardner. (Glanville 1961, inside dustjacket flap)

Glanville is celebrated here not for his Jewish particularity but as the English response to the hugely successful (non-Jewish) American sports columnist and short story writer Ringgold Wilmer Lardner. Indeed, the blurb plays down the Jewish element also in relation to the stories collected in the volume: "Among many vivid character studies are included two brilliant acid pictures of the prosperous Jewish middle class" (ibid.). In fact, many more of the altogether nineteen stories address 
in one way or another questions of Jewishness. That only the critical perspective on the Jewish middle class is emphasized in the blurb moreover suggests a biased perception of its market value which obviously also takes note of the controversial reception of Glanville's novel The Bankrupts (1958) among the Anglo-Jewish establishment (Sicher 1985, p. 111).

Clearly, "The Survivor" is one of "the two brilliant acid pictures" invoked in the blurb. The story is about an eastern European Jewish refugee boy taken in by an Anglo-Jewish family after the war and subsequently turned Israeli sailor. From time to time he still visits, instilling in Marion, the Levinson's daughter, the feeling of a "vague, latent menace" (Glanville 1961, p. 111); about the harmless but supposedly more interesting men-friends whom she prefers to him, he irritably comments: "They don't go all over the world. They haven't seen the things that I've seen" (ibid., p. 116). The suggestion is obviously ambiguous and refers implicitly to the Holocaust as much as to his travels. It is also another indication that, ultimately, there is no escape from the things he has seen, no matter how far he may roam the world.

One evening, coming home from a party to the otherwise empty house, Marion finds him drunk on the sofa, "the door of the ravaged cocktail cabinet swung open like a betrayal" (ibid., p. 117). It is the prelude to her rape. The image of the open door recalls that of his arrival, when "[h]e turned up on the doorstep in that awful coat that was miles too big for him, coming down nearly to his ankles, short trousers and an old, torn jersey" (ibid., p. 108). Yet, when Mrs. Levinson reminisces about their initial encounter-transfigured by the uplifting awareness of her own goodness and "[gazing] into space like Joan the Maid, confronted by a secular vision"—-she adds "wonderingly" that "[h]e was like an animal" (ibid., pp. 107-8). The implication is that as a result of her benign influence Marcus has been reclaimed from "all the terrible things that have happened to him" (ibid., p. 115); nor does she tire of reminding her daughter to be grateful for her own better fortune: "God forbid that anything like this should ever happen to you ... " (ibid., p. 108).

The image of the door is then also a warning to consider the consequences of ignorantly and arrogantly admitting the Holocaust into the comfort of Jewish British life. But it similarly suggests that door and lock cannot keep the horror at bay. In the end it is implied that the experience of the Holocaust cannot be domesticated, that the damage done to the individual is transmitted to and wreaks havoc also in the supposedly safe haven inhabited by the Levinsons. The mother's hysterics, no more than her fussing, cannot undo the violation, neither that of the survivor nor that of her daughter. Yet, as her screams conclude the story, this is also a denunciation of her hypocritical righteousness and the futile attempt to distance herself from the traumatic experience: "Get out of my house, you filthy refugee! Get out, get out, get out!" (Ibid., p. 118)

Like Baron's "The Anniversary," "The Survivor" exposes the gristle and bone under the skin of the survivor, and their invisible but festering mental scars. But unlike the much shorter earlier text, which ultimately is sympathetic toward those who flaunt "their victorious fight back to life" (Baron 1954, p. 10), it denounces the hypocrisy of those who sanctimoniously arrogate to themselves the right to patronize and to judge. Nor does it uncover grief and loss, but irreparable damage and violent aggression, which reveal the frailty also of the alleged security of Jewish life in England.

This is also the pattern which informs Ruth Fainlight's "Another Survivor" (1977; Fainlight 1994, pp. 75-83), its title possibly a reference to Glanville's story. It was first published in Emma Tennant's magazine Bananas and later collected in Dr Clock's Last Case and Other Stories (1994). Fainlight was born in New York City but has lived in England since the immediate post-war period and has in many ways written herself into the literary tradition of her adopted country. In addition, her story addresses a topic in relation to the Holocaust which for a long time has remained a specifically Jewish British domain. Its protagonist was on the kindertransport, the British rescue effort which allowed 10,000 children of Jewish descent to escape Nazi persecution between 1938 and 1940.

In "Another Survivor," Rudi represses any memory of his parents and of his own past in Germany. Yet, when he gradually begins to transform the bland house he occupies with his new family with antiques, it emerges that he seeks to recreate his childhood home in Berlin. His subconscious efforts 
extend even to his adolescent daughter whom he begins to mold in the image of his mother. Eventually, his intensifying sense of guilt erupts in violence: Disturbed by the likeness he has fashioned, Rudi tears her dress off his daughter, shattering the illusion, and singling her out as his victim like his mother must have been singled out by someone else. Hurt and upset by her father's inexplicable behavior, the girl screams at him: "Fascist!" Utterly shaken, Rudi flees the house and aimlessly roams the streets "until he reaches the end of his endurance and drops in his tracks" (Fainlight 1994, pp. 82-83).

Paradoxically, Rudi-like Marcus in "The Survivor"-is simultaneously perpetrator and victim. He may have escaped the Holocaust, yet his life is blighted with its sinister specter. His final collapse confirms that the past has ultimately caught up with him, and clearly evokes the infamous death marches occurring during the evacuation of the concentration camps in the face of the advance of the Allies. The suggestion is, as in Baron and Glanville's stories, that the innocence of 'before' the Holocaust cannot be recuperated, that the 'after' is inexorably contaminated with its destructive influence for generations to come.

Fainlight's story addresses the phenomenon of survivor's guilt and the trauma of the Holocaust, suggesting also its inescapable impact on subsequent generations. One Jewish British writer of the immediate post-war generation for whom, as Efraim Sicher maintains, "the Holocaust is a literary obsession that haunts his pseudoautobiographical persona" (Sicher 1985, p. 161), is Clive Sinclair (1948-2018). Sicher supports his contention with reference to "The Creature on My Back" (1978), first published in The London Magazine (Sinclair 1978) and included in the writer's first collection of stories, Hearts of Gold (1979; Sinclair 1982, pp. 85-97). Typical of Sinclair's macabre and darkly humorous writing, the story, set in Canada, shows its traveling narrator indeed beset by an evil-minded (imaginary) creature on his back. The dybbuk-like apparition seeks to claim him and his posterity to Holocaust victimhood. Yet, when he eventually sees a psychologist, his affliction is put into perspective. He is told that he is lucky: "You have a creature on your back. Such things are not common in Canada. It may yet go away. As for myself, I have a number on my arm. A souvenir of Europe" (ibid., p. 97). The reality of the experience of the survivor is emphasized against the phantom of the transmitted trauma. And yet, while there is hope, the latter's psychological impact-the unease it produces-is not in any way diminished.

\section{Between Defeat and Self-Assertion: Antisemitism and Israel}

The psychological impact of the Holocaust is felt in many of Sinclair's stories, if frequently more subtly. Yet, in the context of this article, I want to discuss one of his stories which is indicative of two other "obsessions" of its author, British antisemitism and the critical engagement with Israel. Arguably, no other Jewish British writer has been as vocal about his anxieties about Israeli transgression and its implications on the diaspora.

In Sinclair's work, too, is manifest the centrifugal force described by Bryan Cheyette as "extraterritoriality." His "Wingate Football Club" (1979), collected in Hearts of Gold (Sinclair 1982, pp. 40-50), is initially set in (early) 1960s Britain, but then moves to Israel, once again to return in dejection to England-if with a glimmer of future hope of fulfilment in the Promised Land.

The story interweaves the narrative of British antisemitism with one of Jewish defiance and Jewish victories. The first of these occurs when the all-Jewish Wingate Football Club win the London League Cup (which, in truth, they never did; Football Club History Database n.d.). The predictable antisemitic response- “Hitler was right! Send the Jews to the showers!" (Sinclair 1982, p. 42)—is met with a determined blow which knocks the pugnacious offender out cold and has the narrator reflect: "we had not only won the cup but also a great moral victory over the yoks. They had called us dirty Jews and we had stood up to them and got away scot free; on the contrary, it was they who left with bloody noses" (ibid., p. 43). Indeed, as the narrator then suggests: "Now I realise that part of the fun of going to Wingate was the possibility of encountering just such anti-semitism." The thrill of gaining the moral advantage perversely vindicates the confrontation and reaffirms Jewish otherness: "I think we welcomed the anti-semitism because it proved that we were morally superior; it may have confirmed 
our status as outcasts but it also reaffirmed our role as the chosen people" (ibid.). What Sinclair seems to suggest here is that the Jewish inferiority complex is overcompensated and turned into a superiority complex, a notion he continues to explore in relation to Israel.

Indeed, the sweeping Israeli victory in the Six-Day War rekindles the narrator's elation: "I had not felt such exultation since Wingate took the London League Cup" (ibid., p. 46). In a euphoria of identifying with the Jewish state, he and his girlfriend talk about marriage and emigrating to Israel. As the narrator maintains in retrospective irony: "My Jewish destiny was about to be fulfilled" (ibid., p. 47). Yet, that destiny, ultimately, is not one of triumphs-as is exemplified in the fate of the narrator's friend Solomon which exposes the perceived superiority as overcompensation.

During their school days in England, Solomon is the victim of constant antisemitic abuse by teachers and pupils alike. Cowardly and anything but an athlete, the Jewish boy is the object in particular of the vicious attacks of their games teacher, nicknamed Beaky. Yet, when the narrator meets Solomon years later in Jerusalem, "[h]e was no longer the weedy Yid of our school-days; instead he moved through the city with self-confident ease. A man among men, a real Yiddisher mensh" (ibid.). Nevertheless, to Solomon-hero of the Six-Day War and embodiment of the New Jew of Zionist ideology—all his victories are still in response to the antisemitic humiliations he suffered at Beaky's hands. His final triumph comes when he is chosen to represent Israel at the Olympics. Yet, the year is 1972 and the Olympics those in Munich where the Israeli team was taken hostage by Palestinian terrorists and all athletes were killed.

Jewish victory is turned into devastating defeat when the narrator imagines his friend's thoughts:

What could he be thinking? Deeper than the politics of the Middle East was he tormented by a single thought? That Beaky was having the last laugh. Solomon could not wrestle with men holding machine-guns; his skills were trumped, he was as helpless as a schoolboy again. (Ibid., p. 49)

In spite of its bleak outlook on the overcompensation of the Jewish inferiority complex- "whatever they did the Jews were doomed to lose out" (ibid., pp. 48-49), and even Wingate is defeated because it eventually accepts non-Jewish players and succumbs to assimilation-the story still ends on a potentially hopeful note, predicated on the promise of Israel yet also on the persistence of the diaspora: "My parents keep nagging me to give them a grandchild. But I want any child of mine to be born in Israel." And quoting from the Seder liturgy: "L'shanah haba-ah birushalayim. Next year in Jerusalem" (ibid., p. 50).

In Sinclair's “The Iceman Cometh" (1996; Sinclair 1996, pp. 119-24)—whose title alludes to Eugene O'Neill's eponymous play (1946) about facing one's delusions-this cautious optimism is further subverted when it transpires that no more male children are born in Israel: Echoing the plagues visited on Pharaoh for holding the chosen people in bondage, nature rebels against the sacrifice of its progeny and the delusion of those sending their offspring into unjust wars. Sinclair's anguished criticism of Israel is amplified here in the aftermath of the controversial Lebanon War of 1982 into an engagement with Israeli transgression and the exploration of his narrators' guilt complex. But already in 1979, Sinclair was a critical observer of Israel, as emerges also in "Wingate Football Club" when the fissures in its societal fabric are exposed with the disdain suffered by oriental Jews at the hands of the Ashkenazim.

\section{Precarious Identifications-Internal and External}

The geographical range of Jonathan Wilson's biography is reflected in the writer's stories. Some are set in Israel, others in transit in various places of the world, still others in America and a few in his native England. It is one of the latter I want to focus on because with its engagement with British antisemitism and Israel it addresses recurrent issues in Jewish British writing.

"Bank Holiday" (1993) is included in Wilson's debut collection of stories, Schoom (Wilson 1995, pp. 23-36). Set in August 1967, it begins with a topographical positioning of the narrator and his friend 
Dennis at the precarious periphery—or frontier—of the more affluent Jewish community in Golders Green. The schoolboys are on their way to the "no-man's-land" of the fun fair at Hampstead Heath. Between the dubious attractions of the "Rat Woman" and the charms of the obviously non-Jewish Pat McNally, "this gorgeous sixteen-year-old girl" whom the narrator is "dying for" (ibid., p. 28), the tale then continues to negotiate the adolescent boy's Jewish identity in relation to his origins, rampant antisemitism, and (implicitly) the Israeli victory in the Six-Day War.

Invited to the painter's studio of Pat's boyfriend, the two schoolboys savor the bohemian atmosphere and the free dope but realize very quickly that the much older Lemberg is nevertheless "one of us." Given away by his accent, Lemberg—based on Robert Oscar Lenkiewicz (Wilson 2020)—is clearly related to the topography of the metropolis and marked as Jewish: "He's from our part of town. So there's not a lot we can do now, because he knows who we are, and we know who he is. That's all it takes in London really, someone opening their mouth" (Wilson 1995, p. 28).

Incited by the heightened perception induced by the drug, the narrator proposes to raise the Israeli flag above his school, a place where antisemitism is endemic and which "mingles semi-intelligent sociopaths from Kilburn with recidivist Jewish kids from Willesden and Wembley" (ibid., p. 29). Faced with the problem of where to find an Israeli flag, the two boys plan to steal one from the synagogue. Yet, when they break in, they find the temple raided, a swastika daubed onto a wall, and the janitor beaten up. Despite the narrator's second thoughts, Dennis eventually continues with the plan and proceeds to hoist the Star of David above the school. The narrator in the meantime waits in the park where he is assaulted by a teenage gang who write the word "JOO" on his back, which he only realizes after his escape when he takes off his T-shirt to wipe his face:

Where once there was a blank, white space, the word JOO is now inscribed; two 'O's-jocularity or ignorance? I pull the stained, soaking T-shirt back on. It's hot enough to walk bare-chested, but I've been exposed, and I want to cover myself. (Ibid., p. 35)

The involuntary act of being "exposed" as a Jew—obviously something to be exposed as, and based on an incident experienced by the author himself (Wilson 2013, pp. 45-47)—is contrasted with the defiant and celebratory display of the Israeli flag just after the victorious Six-Day War. This, however, provokes a disillusioning anti-climax. On the crenelated tower of the school, symbol of its Englishness, "[t]he Israeli flag, that I had imagined rippling in waves of triumph, shiny point of resistance in a constellation of hostility, droops in the windless early dusk" (Wilson 1995, p. 35).

At the end of the day, the incidents of this "Bank Holiday" bring the realization that " $[t]$ here is nothing redeeming about my pain. It is hurt and humiliation, pure and simple, with its own vectors and swoops" (ibid., p. 36). The conclusion of the story sees the narrator with Pat in the darkness of the cinema. Yet, the promise of this new constellation is also disappointed: "In the Hampstead Everyman I think, for about an hour and a half, that I might take hold of her hand, but in the end I don' $\mathrm{t}^{\prime \prime}$ (ibid.).

The customary wry humor of Wilson's narratives takes on a slightly desperate note here in contrast to the sobering conclusion of his story which poignantly projects the narrator's ultimate unease in a society that is endemically antisemitic, with Israel, and with himself. The story augurs not well for Jewish life in Britain and it may not be too far-fetched to relate its resigned mood to the writer's emigration in real life.

"Bank Holiday" was originally published in The New Yorker (Wilson 1993). The American reader would presumably have been mystified by the linguistic topography elaborated by Wilson; even more jarring might have been the story's unresolved ending, which offers no reconciliation between Jewish and British. A conciliatory conclusion was indeed suggested to the writer by his editor at The New Yorker (Wilson 2020). Wilson's insistence on his original conception and the articulation of unease salvaged the story's poignancy. 


\section{Unease in the Lengthening Shadow of the Holocaust}

On the surface, James Lasdun's short story "The Old Man"—first published online in A Public Space in 2008 (Lasdun 2008) and collected in It's Beginning to Hurt (2009; Lasdun 2010, pp. 53-68)-is simple enough. Yet, it has sinister undertones giving expression to a palpable unease which at the same time make it a 'Jewish' story. Lasdun, born in London in 1958 and now living in upstate New York, does indeed have a Jewish background. He is not, however, usually considered a Jewish writer. Categorization in a case like his is difficult anyway-should one see him as a British writer or as an American? Or, after all, as a "hyphenated" writer: British-American and, to complicate matters, Jewish?

The old man occupying the cottage behind the greenhouses has disappeared. He was a distant relative of Olga and Lydia, the mother and middle-aged daughter who with hard work and dedication have created a new life for themselves in the US after their flight from Czechoslovakia. But now, Mirek is gone. He did not pay the rent for three months. Obviously, they had to get rid of him. To make room for the foreman and his family. Conrad, about to open a bottle of champagne in anticipation of his wedding with Lydia, is bemused when he hears that the old man is gone.

The identification of "The Old Man" as a Jewish story may appear to be speculative. And yet, there are good reasons to consider this particular story to be 'Jewish.' When Olga, the old woman, spits: "He did not want to work!" (Lasdun 2010, p. 95); and when Lydia, the bride to be, says: "I left him at the train station" (ibid., p. 96), this seems no less ominous than Conrad's vague response:

"I see," Conrad said. It seemed to him that he had received some momentous intelligence and that he needed to absorb it, but at the same time he was uncertain why any of this should concern him at all, let alone disturb him. (Ibid.)

Mirek's sudden disappearance, the claims that he was not willing to work, his suggested train journey, the appropriation of his living quarters and, not least, Conrad's uneasy bystander role all contribute to summoning up the dim specter of the Holocaust. German words, such as "Nacht und Nebel," "arbeitsscheu" or even "Arbeit macht frei," "Lebensraum," and "Mitläufer"—fraught in the historical context of the Holocaust-come to mind, as do the deportations by train.

While none of this is really tangible, I argue that it nevertheless provides the 'Jewish' substratum to Lasdun's story, a substratum, as suggested above, of "not saying" and "nonetheless saying," of unease. Recognition of this substratum then transforms "The Old Man" into a story about the individual's responsibility to challenge and actively resist the persecution of the potential victim. The vague allusion to the Holocaust invokes the lesson, but also the guilt, of the historical conflagration and projects it into our everyday experience as an ethical imperative.

Once such a Jewish substratum has been identified, other stories of Lasdun's reveal similar roots (Malcolm 2008, pp. 336-37). And I do not mean just the Jewish provenance of some of the names the author chose for his characters, as in the case of "Peter Kahn's Third Wife" (Lasdun 2006) first published in New Writing (Lasdun 2010, pp. 209-22). For instance, can the reference to surviving in "The Incalculable Life Gesture" (ibid., pp. 55-68), also collected in It's Beginning to Hurt and previously unpublished, be read without associating notions of the Holocaust? Obviously, I may be reading Jewishness into these texts where there is none. After all, Richard Timmerman in Lasdun's story survives not even cancer, but no more than the anxiety of a lump, which then turns out to be harmless. Yet, can the mere reference to "surviving" really be separated from the phantom of the Holocaust?

In the story, Timmerman remembers visiting the Cancer Survivors Park in Minneapolis, and although its real entrance does not at all look like that of Auschwitz, Lasdun's description of "stencilled metal letters over the gate" (ibid., p. 62) is strangely suggestive of the notorious image. As is the insistence on the name's "brazen literalness where some euphemism might have been expected" (ibid.) - the sort of euphemism, presumably, that was encapsulated in the notion of "Arbeit macht frei." And yet the inscription in Minneapolis and its "summons to celebrate the afflicted" make Timmerman "recoil from the very thought of such ghoulish beings" (ibid.). Does this extend, then, to the ghoulish existence of those who survived the Holocaust, such as in Glanville's and Fainlight's 
stories? The symbolic value of the original Auschwitz sign has been described as positioned on the "threshold between our world and the concentrationary universe" and "at the flexible and very artificial line between history and memory" (Stier 2015, pp. 96, 99). Is the survivors' continued existence and the continual reminder of their affliction then an intrusion into post-Holocaust reality that puts into perspective all other instances of survival and sparks a flare of unease?

Lasdun's reflection on the ambiguous dimension of the notion of surviving, though much more serious and subtle, is reminiscent of an episode of the HBO TV sitcom Curb Your Enthusiasm entitled "The Survivor" and aired in March 2004 (Charles 2005). Controversially, the comic potential of the episode derives from a misunderstanding which leads to the confrontation at a party of a Holocaust survivor with a "survivor" of the eponymous CBS TV show. Both challenge the other's claims to authenticity and the severity of their respective ordeals. The scathing satire, written by Larry David, arguably targets the inflationary use of the term as exemplified by the fatuous "reality" celebrity show no less than its 'sacralization' in Holocaust discourse.

The "critique of American Holocaust pieties" (Rothe 2011, p. 3), and in particular of the survivor trope, reflects also on the development of Jewish American literary engagement with the Holocaust. As in Britain, this was initially hesitant, though frequently implicit. To begin with, it was particularly the trope of the immigrant survivor which was employed by writers such as Saul Bellow, Edward Lewis Wallant, and Cynthia Ozick to reflect on the geographically distant cataclysm (Krijnen 2016, p. 110), similar to, but less brutal than, Glanville. The so-called Second Generation of survivors in Jewish American literature, prominently including Art Spiegelman, Melvin Jules Bukiet, and Thane Rosenbaum, confronted the Holocaust much more directly, mostly in relation to the experience of intergenerational trauma. Younger Jewish American writers of the third generation, finally, while still writing "about the Holocaust in implicit and oblique, rather than direct or realistic ways," offer a more varied engagement with the historical occurrence (ibid., p. 111). As Joost Krijnen notes, "they are writing in a period when this history has become a central component of the Jewish American experience that positively reinforces Jewish American identity" (ibid.). These writers, among them Michael Chabon, Jonathan Safran Foer, Nicole Krauss, Nathan Englander, and Shalom Auslander, appear to have overcome the "inherent reluctance to confront the Holocaust" which encumbered earlier generations (ibid.).

Lasdun, arguably situated between American and British, seems to align with this approach. Still, to identify the putative Jewish substratum of his stories in relation to the Holocaust is certainly problematic in that it ties notions of Jewishness to Jewish victimization. Nevertheless, as Ilan Stavans maintains-if somewhat reductively - the Holocaust "forced upon the Jewish writer a less dilettantish, more responsible role: he could not longer [sic] perceive himself as an imaginer and impersonator; instead, he was suddenly called to be a witness and an archivist" (Stavans 1998, p. 17). Cheryl Alexander Malcolm insists even more categorically that "[a]fter the Holocaust, every living Jew is a survivor" and that "the Holocaust and the Jewish writer are by now inseparable" (Malcolm 2008, p. 330). There is indeed copious evidence that the historical conflagration continues to overshadow Jewish literary production, if sometimes implicitly, as in the case of Lasdun. It would, however, be wrong to limit the perception of Jewish writing and its putative substratum of unease to the response to the Holocaust which, moreover, as Jon Stratton puts it, has evolved into "a recognized part of the Western cultural imaginary" and as such has generated literary responses in many different ways and contexts (Stratton 2007, p. 126).

\section{The Threat of Fragmentation: Wandering and Memory}

The extraterritoriality of Jewish British short story writers and of their narratives appears to confirm the significance of the diasporic experience as one of exile and wandering. While it would certainly seem facile to attribute this thematic preoccupation merely to the hoary stereotype of the "wandering Jew" (Anderson [1965] 1991), it may well originate in the historical precariousness informing much of the Jewish experience. The attempt to create narrative coherence beyond the short story form, while 
nonetheless focusing in individual sketches on the wanderer, is therefore of particular interest. Gabriel Josipovici's collection Goldberg: Variations (2002; Josipovici 2002) and Tamar Yellin's Tales of the Ten Lost Tribes (2008; Yellin 2008) are intriguing examples of this phenomenon.

The thirty interconnected short stories of Josipovici's collection, as suggested by its title, by and large follow the musical pattern set by Johann Sebastian Bach's Goldberg Variations (1741; BWV988). Simultaneously, they adapt the story of Johann Gottlieb Goldberg: The harpsichord virtuoso supposedly played the variations to his patron, Count Hermann Carl von Keyserlingk, so he would overcome his debilitating insomnia. In Josipovici's collection, the German Jewish writer Samuel Goldberg is similarly employed by the country gentleman Tobias Westfield Esq. He acts with his nightly new stories almost like a reverse Sheherazade, not to keep Westfield awake but to aid him in finding the yearned-for sleep.

Josipovici's short pieces range a-chronologically and non-sequentially from the eighteenth century to the present. Occasionally complementing and confusing Goldberg as narrator with a persona more like that of the author, the fragmentary, mosaic-like nature of Josipovici's stories confronts the reader with incessantly shifting perspectives on seemingly disparate occurrences. Eventually, however, a closely woven tapestry emerges in which past and present intertwine. Ultimately, the reader is matter-of-factly returned to the cycle's beginning-as is the listener in Bach's conclusion of his variations.

Josipovici's text, characterized by the colon between the words in its title, is far too intricate to follow all the narrative strands and motifs explored in the individual stories; nor would it seem feasible to encompass the plethora of intertextual references informing his collection, but some are clearly more obviously pertinent than others. Thus, next to Bach's Goldberg Variations, the composer's The Art of Fugue (1751; BWV1080) and the formal characteristics of the fugue represent important intertexts. In contrast to the essence of melody, which is described by one character as "solitude and the melancholy of solitude," the essence of the fugue is identified as dance, understood to mean "well-being in reciprocity" (Josipovici 2002, p. 133). Ultimately, "the joy of the art of fugue" is therefore "that words like first and last lose all their meaning" (ibid., p. 139). Like the notion of variation, the inventive circularity of the fugue is a fundamental structural principle applied by Josipovici to his Goldberg: Variations.

The reciprocity embodied by the fugue links in the thirty short stories the narrator Goldberg and the alter ego of the author also with the tragic figure of Friedrich Hölderlin. Skillfully conflated with elements from Georg Büchner's influential fragmentary novella Lenz (1839), "Sinclair," the thirteenth of the stories offers a variation on the German poet's life through Goldberg as focalizer and challenges the common belief in his madness in later years. In the following story, "Unterlinden," the author's alter ego, despairing over writing the book we read, cites from the second version of Hölderlin's "Mnemosyne" (1803):

A sign we are, without interpretation

Without pain we are and have almost

Lost our language in foreign parts. (Josipovici 2002, p. 99)

The hymn, "supposedly written in the poet's madness" (ibid.) and notoriously difficult to interpret (Roland-Jensen 1989), interrogates the nature of memory. To Josipovici, citing its opening lines out of context, the cryptic text seems to suggest not only the breakdown of communication-which is borne out in this story by the narrator never having anticipated the separation with which his wife suddenly confronts him; it moreover appears to signify the human condition, of which it seems to be an integral element to wander "foreign parts."

Applied to the context of Anglophone Jewish writing, Hölderlin's despair over the loss of the meaning of signs gains significance in relation to the loss of (former) Jewish languages and the inevitable loss, or transformation of, meaning which the process of making another language one's own entails. As Josipovici is 'intertextually' situated at the very margins of Jewish British writing-as 
are, geographically and culturally, Lasdun and Wilson-the émigré writer evokes another level of unease, the lost cultural affiliation with German language and literature and its meaningful signs.

The notion of existential foreignness articulated by Hölderlin and embraced by Josipovici is connected in Goldberg: Variations to Paul Klee's 1940 painting Wander-Artist (Ein Plakat), first introduced in the previous "variation" but also the cover image of the original Carcanet edition of 2002. In fact, the writer's representation of the Wander-Artist emerges as a unifying device that suggests an interpretive key to the collection as whole.

Josipovici's twenty-seventh "variation," entitled eponymously with Klee's picture, is particularly illuminating in this context: "Here I am, one hand raised in mock salute, on my way to the other side," it begins from the perspective of the stick figure-like image. "To the other side of what? It does not matter. The other side" (Josipovici 2002, p. 179). The figure was created by Klee in the last year of his life after he had been suffering from (undiagnosed and fatal) scleroderma for several years. Josipovici's reading of the Wander-Artist accentuates its existential(ist) dimension. "It does not matter," he continues the figure's imagined dramatic monologue, "where I have come from. You could say that I am only alive when I come into view and where I am going is anyone's guess" (ibid.).

The philosophical penetration of the stick figure is suggested through its metaphorical relevance to the collection's challenging search for an understanding of self and world. It embodies an in-betweenness between being and not-being, between knowing and not-knowing, light and dark; its essential nature is that of the wanderer between worlds who acts as a catalyst but whose existence is precarious. Yet, the striding and waving figure, as the mediator between history and invention, turns in Josipovici's story also into a metafictional reflection:

A little corner of the world. Of a world which never existed and is not exactly an invention either. I am witness to that.

To put it another way: If I was not here, passing through, there would be either the dead weight of history or the dead weightlessness of pure invention. I am passing through: Pay attention and you may catch a glimpse of me. (Ibid., p. 180)

The nature of narrative as a means of creating meaning emerges when Gerald, the author persona, despairs in the twenty-fifth variation of his ability to complete his story collection, which he nevertheless also cannot leave. "You have to feel that more is at stake than the skillful telling of thirty anecdotes," he agonizes: "You have to feel that each is valid in itself and yet that all will add up to more than the sum of the parts" (ibid., p. 173).

His desperation is mirrored in the reason for Westfield's insomnia, the imagined burden of having to hold the world together because "[i]f he relaxed for even an instant the world threatened to fly apart into a myriad fragments or else simply to fizzle out" (ibid., p. 15). It is the recognition that every story is made up of details but also of "something else" —of that "which lies in between" — which creates coherence and cohesion and the envisaged narrative surplus through elusive slivers of meaning. Yet, if one were to see the importance of between it would, as the twenty-sixth variation, entitled "Between," reminds us, "no longer be between and so would no longer be what is important" (ibid., p. 177). The paradox is resolved with the figure of Klee's Wander-Artist turned metaphor.

Significantly, the twenty-first variation, "The Lord of Time," anticipates the later interpretation of the Wander-Artist when Westfield ponders the "enigma of Goldberg" (ibid., p. 154). The Jewish writer, like the iconic image, is a wanderer: "I do not know where he comes from, [Westfield] thought, and I do not know where he is going, but the strange thing is that he seems merely present. As though coming and going were not concepts applicable to him" (ibid.). While Goldberg is clearly identified as Jewish in Josipovici's stories and while it is his Jewishness which appears to determine his nature as a man "who understands" (ibid.), not least because of the significance which Judaism attaches to memory, his wandering-like that of the Wander-Artist—does not emerge as specifically Jewish but rather as constitutive of the modern, if not the human, condition and as a way of understanding self and world. 
Born in 1940 in Vichy France to Jewish parents, in the very year of Klee's creation of the Wander-Artist and of his death, Josipovici after the war went to school in Egypt and emigrated to Britain in 1956. The writer's personal biography as an émigré may well have informed his Goldberg: Variations. Yet, wandering is also a central motif in Tamar Yellin's Tales of the Ten Lost Tribes (2008), in which each of the interlinked short stories is associated with one of the lost tribes of Israel. Yellin too (b. 1963), though born in the north of England, has a cosmopolitan family background. Her father was "a third generation Jerusalemite and her mother the daughter of a Polish immigrant," and the writer describes "the creative tension between her Jewish heritage and her Yorkshire roots" as a defining feature of her work (Yellin 2008, p. 157).

While certainly very prominent in Yellin's first collection of short stories, Kafka in Brontëland (2006), this creative tension may be less pronounced in Tales of the Ten Lost Tribes. It is nevertheless the latter I want to discuss here. A significant element also of her earlier collection, the motif of wandering and not-belonging pervades Yellin's Tales as a structural principle. In fact, the writer's second collection ambivalently explores the wanderer's search for home and belonging. Its first story elaborates the disillusionment of the glamorous explorer-wanderer, the narrator's uncle, who vanishes forever after leaving the child with the charm of a lemur's foot in exchange for her mother's diamond ring. It is this charm which, years later, is clutched by the narrator of Yellin's concluding story, which brings her collection full circle. Traveling up-river in an exotic land "deeper and deeper into the heart of the forest" (Yellin 2008, p. 151), the narrator is racked with fever, left by her guide, and unable to communicate with the locals as she enters her own heart of darkness.

As with Josipovici's Variations, each of Yellin's stories is "valid" in itself but they nevertheless add up to more than the sum of the parts by associating the fate of the Jewish individual with that of the fabled ten lost tribes of Israel who, according to legend, are trapped behind the raging river Sambatyon which will only rest on the Sabbath, when the Jews of course are not allowed to travel. It is hardly a coincidence that "Menasseh," the last of the ten stories, each named after one of the lost tribes, evokes another river which brings the journey of the narrator to an uncertain end. It culminates in the search for a mythical Jew called Isidore, like another Kurtz, of whom conflicting stories are told. The version the narrator is finally left with suggests

that he was not a native of the place at all, but a traveller from the outside world like us, who had wandered into the jungle and lost himself; and that throughout the years of his wandering he had parted with his identity piece by piece, until he was neither one thing nor another, too strange to be a native, too far gone, now, ever to return. (Ibid.)

Isidore- "for some reason" translated by her guide as "the Jew" (ibid., p. 147)—is the epitome of the wanderer (is he her lost uncle?) and, as the narrator says of herself, of the "perpetual foreigner" (ibid., p. 118). In the preceding story, in which she is confronted with the invisibility of those who are unacknowledged and ignored, she affirms her own affiliation: "I chose to identify among the lost: that hidden tribe of wanderers and strangers, aliens and misfits to which I too belonged" (ibid., p. 104). Yet, she is nevertheless challenged by the "invisible" Genie-a young woman whose passing through her life resembles Josipovici's notion of the Wander-Artist-with a painful truth: "You want to go home [ ... ] but there is no such place" (ibid., p. 110). The whole of Yellin's Tales of the Ten Lost Tribes is permeated with this uneasy sense of weariness, of the eternally and excruciatingly thwarted quest for belonging

It is manifest also in a story about the narrator's father. In contrast to the uncle mentioned earlier, the adventurer, "tanned and dynamic," her father was "sedentary and pale" (ibid., p. 12). He was a businessman, but was also always interested in books:

It was as if he must handle all the books in the world, even if he did not actually read them. They must pass through him like sand in an hourglass. Perhaps he retained a grain or two of knowledge; nevertheless, the pursuit was unstoppable. (Ibid., p. 42) 
In what appears to be a strange form of reverse wandering, in which it is the books that travel, it is nevertheless constant movement which emerges as the basis for the narrative creation of meaning:

How many interminable hours I sat with him while he worked on that massive compilation, his Tales of the Ten Lost Tribes, and while he constructed, bridge by difficult bridge, the hidden network which connects us all. For this was my father's secret undertaking: to trace migrations and reclaim names, to exhume the missing and retrieve the dead; to create a synthesis of all he had read and learned, and set it down at last in some kind of order, a map of the maze in which he had lost himself. (Ibid., p. 47)

Reminiscent of Westfield's insomnia-inducing anxiety in Goldberg: Variations, the world appears to be a volatile construct fatally at risk without the active creation of narrative coherence:

His memory could only hold so much. So often when I came across him reading, his finger was pressed to the centre of his forehead, as though to keep in place the precarious knowledge which threatened constantly to fly apart. (Ibid.)

The existential anxiety articulated here echoes the unease expressed with Josipovici's reference to Hölderlin, but it is turned on its head. Here, it is not the loss of meaning which threatens catastrophe, but its proliferation - the desperate need to establish coherence and cohesion in the face of an ever increasing profusion of meaning which ultimately threatens to explode all meaning.

\section{Dissonances and Resolutions}

The relatively recent proliferation of interweaving story cycles—such as Josipovici's and Yellin's or, published posthumously in the year of his death, Sinclair (2018)—suggests not only the increasing prominence of these Jewish writers in a larger British context but also an emerging pattern of the pursuit of the transcendence of the meaning of individual stories, of the amplification of the sum of the parts. Michelene Wandor's False Relations (2004; Wandor 2004) is another collection which succeeds very well in achieving this objective. Blending her avowed feminism with a specifically Jewish perspective, Wandor (b. 1940), like Josipovici in Goldberg: Variations, explores musical resonances in her own stories of wandering. The very title of her collection is taken from music theory, where the term refers to "[a] contradiction between two notes of the same chord, or in different parts of adjacent chords," as the epigraph to the title story explains (Wandor 2004, p. 67). Herself an accomplished musician, the writer produced in 2002 with the Siena Ensemble a recording of the long-neglected music of the early seventeenth-century Jewish composer Salamone Rossi to which she also contributed a poem and the introductory text (Rossi 2002). It is in the context of this labor of love that her collection False Relations needs to be considered.

Like the life of the composer, who appears in the title story and who worked in Mantua under the patronage of the Gonzaga, some of these stories are set in or revolve around the Italian city. Yet, beyond musical allusions, the figure of "the Jewish Princess" emerges as an even more pervasive connecting device. From her expulsion from Spain in 1492 in "Song of the Jewish Princess" (ibid., pp. 11-22), the reader follows her trajectory in different stories to Mantua in "Corridors of Light and Shadow" (ibid., pp. 23-54), to the present in England in "Toccata and Fugue" (ibid., pp. 91-105), and finally to the biblical past in "The Story of Esther and Vashti" (ibid., pp. 153-80).

Interweaving two typographically and stylistically distinct threads of narrative which illuminate one another in the manner, more specifically, of "false relations" or, as the case may be, of "harmony" (ibid., p. 121), most of Wandor's stories articulate a form of polyphony. The theoretical term of false relations is in fact turned into a metaphor for the bond between Rossi and his so much more famous contemporary Claudio Monteverdi. The title story (ibid., pp. 67-89) elaborates on the friendship of the Jew and the gentile and posits that, like Monteverdi's L'Orfeo (1607), the first opera, the composer's most celebrated sacred work, the Vespro della Beata Vergine (1610), was a secret collaboration of both and that it was crucially inspired by the liturgical music they witnessed at the synagogue in Mantua. 
The point is that, as Rossi maintains in the story, "Claudio and I had so much in common: we Jews had so much in common with Catholic musicians: no real distinction between sacred and secular music" (ibid., p. 82) -in spite of the historical proliferation of antisemitism of which the ghetto of Mantua became a victim and which, in Wandor's story, sees Rossi leave for Venice in 1628, there to reunite with Monteverdi; although this, historically, is purely conjectural. No trace remains of Rossi after the sack of Mantua in 1630 and the antisemitic excesses of the victorious imperial troops.

In affirmation of the mutual understanding of both composers, "False Relations" ends with the continuation of the definition of the musical term provided at its beginning: "One consistent qualification makes false relations acceptable: the falsely related voices or parts are nevertheless melodically coherent in themselves" (ibid., p. 89). This promise of co-existence and of mutual understanding is transposed in the concluding story of Wandor's cycle to the context of present-day Israel.

In Hebrew, yom tov literally means "good day"; but it also refers to religious holidays. In Wandor's eponymous story (ibid., pp. 181-90), a middle-aged woman revisits the kibbutz where, as a child, she survived a terrorist raid. The Arab Israeli who saved her was shot in the act and was afterwards "despised by both sides" (ibid., p. 188). By a quirk of fate, the same man drives her taxi. En route they realize that they both "know the same piece of music" (ibid., p. 187): Bach's French suites (BWV812-817) connect them across the rifts of ethnic strife and of time.

This story, too, is divided into two narrative threads-the present, and the woman's hazy memory of the terrorist attack. Yet, like the false relations they are, there is no final convergence between the two narratives. Nor is an open acknowledgment conceded of the shared past between the woman and her driver, the girl and her rescuer. The only tangible object connecting both strands is a recorder, originally given to the girl by the Arab and buried by her before she left the kibbutz; recovered by the grown woman, the dirt-caked instrument is also the reason why they realize that they both know the same music.

The narrative of the past concludes with another remembered and obviously allegorical image: Of eating the sweet sabra fruit and of the spines of the cactus embedding themselves ever deeper in the skin if not removed with tweezers (ibid., p. 190) —an indication of the festering presence of the unassimilable other. The narrative of the present, parallel yet wide apart, sees the woman in the lobby of her hotel drinking tea and iced water, the recorder in her bag - the present to the past like the woman to the girl and the woman to the man, all false relations.

\section{Disobedience and Dissolution?}

Religion, obliquely referred to in Wandor's collection, is not a concern in any of the other short stories discussed so far. It is no longer Judaism that is embattled, but Jewishness; though the very distinction between both poses a challenge to traditional Jewish identification patterns. The correlation between both is mischievously interrogated by Naomi Alderman (b. 1974) in her short story "Other People's Gods" (2009; Alderman 2009). Alderman's acclaimed first novel Disobedience (2006) chronicles the revolt of a young lesbian woman against the strictures of Jewish orthodoxy. In "Other People's Gods," shortlisted for the BBC Short Story Award in 2009, the writer returns to the question of religion and once again, if in a very different way, challenges the notion of obedience to its precepts.

The story's concise first sentence already indicates its trajectory: "Mr Bloom led a blameless life until he saw Ganesha" (ibid., p. 15). Mr. Bloom, as the story continues, had had many dreams. But he, as most of us do, succumbed to reality and the blameless life charted for him by others. When in middle age he chances among the bric-a-brac of a market stall upon a plaster image of the Elephant-headed Hindu god of obstacles, beginnings, and of letters and learning, the idol exerts an irresistible attraction on the disenchanted optician. Weighing the plaster cast in his hands, he ponders the destruction by Abraham of his father's idols:

When his father punished him, Abraham said, “No, father, it wasn't me, it was the biggest idol. He took a stick and smashed all the others." His father said, "You idiot, idols can't move!" and Abraham replied, "So why do you worship them, then?" The story does not 
relate whether at that moment Abraham's father was enlightened, or whether, on the contrary, he punished Abraham yet harder for stripping him of the beliefs which, in prehistoric Mesopotamia, must have been even more precious than they are today. (Ibid., pp. 16-17; see Genesis Rabbah 38.13)

And yet he purchases the pink figurine. At home, it soon finds its way from its initial hiding place in the wardrobe of the spare room into the living room, vindicated by Mrs. Bloom's verdict that it is "very ethnic" (Alderman 2009, p. 20). Her empty phrase is an implied indictment of what is not so much tolerance but indifference and the loss of meaning and coherence in contemporary multicultural Britain, a fashionable but undiscerning infatuation with the other-another instance of the encroaching hollowness of signs in "foreign parts." Before long, the whole family defer to the idol. When news about the perturbing behavior of the Blooms reaches the rabbi, he interviews the mild-mannered idolater and eventually throws his Ganesha out of the window, even though Mr. Bloom insists: "But I still keep the laws. I still pray to God. I'm still a Jew" (ibid., p. 26).

The story's conclusion sees Mr. Bloom with an axe in the wreckage of the synagogue. Challenged by the horrified officials, he insists: "I? I? I did not do this. This was done by the Almighty." To which the indignant response is: "God did not do this! God cannot destroy in this way." The point of the story, as soon becomes clear, is to draw an analogy to Abraham's iconoclasm and his father's ire. Axe in hand, Mr. Bloom now challenges the synagogue's officials: "Then why do you worship Him?"- only for the story to conclude drily: "But it is not recorded whether the people were grateful for this enlightenment" (ibid., p. 31).

As Sue Vice observes:

The narrator's voice, using a stylised version of Biblical discourse, emphasises the black comedy of setting in parallel the worship of the kitsch Ganesha [ ... ] and socially ratified Jewish religious belief. It is as if the 'other people' of the story's title are the Jews themselves. (Vice 2013, p. 103)

Indeed, Vice argues that Alderman's story is the articulation of a particular defensiveness which suggests "that Jewish religious observance can only be represented [ ... ] with the double-voicedness of satire" (ibid.). Ruth Gilbert, in contrast, suggests that Alderman "presents here another fable about disobedience, in this case the worshipping of idols, which suggests that Jewishness cannot remain impervious to the influences around it within the diverse conditions of contemporary Britain" (Gilbert 2015, p. 218).

In an interview with Prospect Magazine in which her story was published in February 2010, Alderman herself maintained that to think that religion was just about belief was too simple. She emphasized: "There's community, hope, superstition, longing, tradition and personal growth all woven together" (Alderman 2010, p. 84). Indeed, it would seem that the writer does not so much address in her story the transcendent point of reference of any belief system. Rather, she understands it as a social construct which, if it fails, loses its cohesive force and threatens dissolution. "Other People's Gods," no matter how humorous it may be, is therefore also another articulation of profound unease in relation to the shifting parameters of Jewish identities.

\section{Conclusions}

Naomi Alderman said that she initially wrote her story to make herself laugh (ibid.), and there is clearly a comic dimension to "Other People's Gods." Jonathan Wilson and Clive Sinclair too infused their stories with their own distinct brands of humor. Common to all three is that the laughter becomes strained because it is stifled by the unease these stories emanate. In fact, although thematically very different, all of the Jewish British stories in English discussed here convey a sense of the unease which I understand to originate in the "inherited" and "communal" traumas informing the Jewish experience.

The Jewish British short story in English, it is needless to say, extends far beyond the few samples discussed here and, more particularly, it extends also much further back in time than the period 
since 1970. Writers as diverse as Benjamin Disraeli, Grace Aguilar, Israel Zangwill, Wolf Mankowitz, and Gerda Charles as well as Ruth Prawer Jhabvala and many others have made significant contributions to it. Similarly obvious should be that its multi-directional connecting threads are not limited to 'Jewish' writers but link their work with other traditions, making the distinction between Jewish, or not, frequently an arbitrary one and sometimes perhaps even impossible or irrelevant.

To Jewish British writers, in danger of becoming ensnared in the tension between Jewish and British, the Anglophone sphere offers the release of their extraterritoriality as it has been described by Bryan Cheyette into a freely accessible and comfortable linguistic and cultural space which is adaptable to their needs. More specifically, it accommodates the unencumbered articulation of a Jewish substratum, determined by a sense of unease, which is frequently at odds with established notions of Britishness. As such, it explains and supports the geographic dispersion of Jewish British writers no less than their literary extraterritoriality.

These writers-Jewish and British by voluntary affiliation or descent-explore in their stories different degrees of propinquity to both of these identifiers. Unsurprisingly, the Holocaust frequently emerges as an ineluctable trauma, explicitly or implicitly, as in the short stories by Brian Glanville, Ruth Fainlight, Clive Sinclair, and James Lasdun. Yet, it is by no means the only constituent of the unease informing the pervasive Jewish substratum of the Jewish British short stories discussed here. Without exception, they explore various contact zones; but in none of them is Jewishness fully at ease with its others, nor necessarily with itself, as is most palpable perhaps in the stories by Glanville and Alderman and in Sinclair and Wilson's engagements with British antisemitism and Israel. In some instances, most notably in the more recent short story cycles by Gabriel Josipovici, Tamar Yellin, and Michelene Wandor, there is a tangible regret about the loss of meaning and of potential entailed by the loss of transcultural exchange that extends far beyond the Anglophone sphere and that settles on the writer the burden of (re-)creating narrative coherence and meaning.

All the stories discussed here offer different responses to the unease informing the Jewish substratum, employing different tropes and ranging from humorous and satirical to serious. Their very thematic plurality and geographical dispersion demonstrates the porousness and instability of the notion of 'British-Jewish literature,' which may have moved beyond the margins, as maintained by Efraim Sicher (Sicher 1985), but whose trajectory, to stay with Sicher's image, in fact has taken some of it beyond the center and out the other side into the Anglophone sphere and Anglophone Jewish literature.

Funding: This research received no external funding.

Conflicts of Interest: The author declares no conflict of interest.

\section{References}

Alderman, Naomi. 2009. Other People's Gods. In The BBC National Short Story Award 2009. London: Short Books, pp. 15-31.

Alderman, Naomi. 2010. Other People's Gods. Prospect Magazine 167: 84-88.

Anderson, George K. 1991. The Legend of the Wandering Jew. Providence: Brown University Press. First published 1965. Baron, Alexander. 1954. The Anniversary. Jewish Quarterly 1: 7-10.

Budick, Emily Miller. 2007. Literary Symptomology and Jewish Fiction: "Envy; or, the New Yiddish in America.". In Anglophone Jewish Literature. Edited by Axel Stähler. Abingdon: Routledge, pp. 79-92.

Charles, Gerda, ed. 1963. Modern Jewish Stories. London: Faber and Faber.

Charles, Larry. 2005. The Survivor [2004]. In Curb Your Enthusiasm: The Complete Fourth Season. New York: HBO Video. Cheyette, Bryan, ed. 1998. Contemporary Jewish Writing in Britain and Ireland: An Anthology. London: Halban. Conan Doyle, Arthur. 2008. Tales of Unease. Edited by David Stuart Davies. London: Wordsworth. Eyre, Sarah, and Ra Page, eds. 2008. The New Uncanny: Tales of Unease. Manchester: Comma Press. Fainlight, Ruth. 1994. Another Survivor. In Dr Clock's Last Case and Other Stories. London: Virago, pp. 75-83.

Football Club History Database. n.d. Available online: http://www.fchd.info/WINGATE.HTM (accessed on 17 May 2020).

Fyvel, Tosco R. 1963. The Jewish New Wave. Jewish Chronicle, September 13, pp. 37, 44. 
Gilbert, Ruth. 2013. Writing Jewish: Contemporary British-Jewish Literature. Basingstoke: Palgrave Macmillan.

Gilbert, Ruth. 2015. Jewish, Half-Jewish, Jew-ish: Negotiating Identities in Contemporary British-Jewish Literature. In The Edinburgh Companion to Modern Jewish Fiction. Edited by David Brauner and Axel Stähler. Edinburgh: Edinburgh University Press, pp. 210-20.

Gilman, Sander L. 1998. Series Editor's Introduction. In Contemporary Jewish Writing in Britain and Ireland: An Anthology. Edited by Bryan Cheyette. London: Halban, pp. ix-x.

Glanville, Brian. 1961. The Survivor. In A Bad Streak and Other Stories. London: Secker \& Warburg, pp. 107-18.

Josipovici, Gabriel. 2002. Goldberg: Variations. Manchester: Carcanet.

Kreitman, Esther. 2004. Blitz and Other Stories. Translated by Dorothee van Tendeloo. London: David Paul.

Krijnen, Joost. 2016. Holocaust Impiety in Jewish American Literature: Memory, Identity, (Post-) Postmodernism. Leiden and Boston: Brill Rodopi.

Lasdun, James. 2006. Peter Kahn's Third Wife. New Writing 14: 1-10.

Lasdun, James. 2008. The Old Man. A Public Space. Available online: http://apublicspace.org/magazine/detail/theold-man (accessed on 17 May 2020).

Lasdun, James. 2010. It's Beginning to Hurt. London: Vintage.

Malcolm, Cheryl Alexander. 2008. The Anglo-Jewish Short Story since the Holocaust. In A Companion to the British and Irish Short Story. Edited by Cheryl Alexander Malcolm and David Malcolm. Oxford: Wiley-Blackwell, pp. 330-41.

Ozick, Cynthia. 1970. America: Toward Yavneh. Judaism 19: 264-82.

Roland-Jensen, Flemming. 1989. Hölderlins Muse: Edition und Interpretation der Hymne "Die Nymphe Mnemosyne". Würzburg: Königshausen \& Neumann.

Rossi, Salamone. 2002. Salamone Rossi Hebreo Mantovano [CD]. Siena Ensemble with John Shrapnel. London: The Classical Recording Company.

Rothe, Anne. 2011. Popular Trauma Culture: Selling the Pain of Others in the Mass Media. New Brunswick: Rutgers University Press.

Sicher, Efraim. 1985. Beyond Marginality: Anglo-Jewish Literature after the Holocaust. Albany: State University Press of New York.

Sinclair, Clive. 1978. The Creature on My Back. The London Magazine 18: 83-95.

Sinclair, Clive. 1982. Hearts of Gold. Harmondsworth: Penguin.

Sinclair, Clive. 1996. The Iceman Cometh. In The Lady with the Laptop. London: Picador, pp. 119-24.

Sinclair, Clive. 2018. Shylock Must Die. London: Halban.

Stähler, Axel, ed. 2007. Anglophone Jewish Literature. Abingdon: Routledge.

Stähler, Axel. 2016. Stories of Jewish Identity: Survivors, Exiles and Cosmopolitans. In The Cambridge History of the English Short Story. Edited by Dominic Head. Cambridge: Cambridge University Press, pp. 323-40.

Stähler, Axel. 2017. Anglophone Literature. In The Cambridge History of Judaism, Vol. 8: The Modern World, 1815-2000. Edited by Mitchell B. Hart and Tony Michels. Cambridge: Cambridge University Press, pp. 727-54.

Stavans, Ilan, ed. 1998. The Oxford Book of Jewish Short Stories. New York: Oxford University Press.

Stier, Oren Baruch. 2015. Holocaust Icons: Symbolizing the Shoah in History and Memory. New Brunswick: Rutgers University Press.

Stratton, Jon. 2007. Punk, Jews, and the Holocaust-The English Story. Shofar 25: 124-49. [CrossRef]

Vice, Sue. 2013. “Becoming English": Assimilation and Its Discontents in Contemporary British-Jewish Literature. Jewish Culture and History 14: 100-11. [CrossRef]

Wandor, Michelene. 2004. False Relations. Nottingham: Five Leaves.

Wilson, Jonathan. 1993. Bank Holiday. The New Yorker, January 11, 92-97.

Wilson, Jonathan. 1995. Bank Holiday. In Schoom. London: Penguin, pp. 23-36.

Wilson, Jonathan. 2013. Kick and Run: Memoir with Soccer Ball. London: Bloomsbury Reader.

Wilson, Jonathan. 2020. Private email communication to Axel Stähler. June 5.

Wirth-Nesher, Hana, ed. 1994. What Is Jewish Literature? Philadelphia: Jewish Publication Society.

Yellin, Tamar. 2008. Tales of the Ten Lost Tribes. New Milford and London: Toby Press.

(C) 2020 by the author. Licensee MDPI, Basel, Switzerland. This article is an open access article distributed under the terms and conditions of the Creative Commons Attribution (CC BY) license (http://creativecommons.org/licenses/by/4.0/). 